\title{
Patterns of Structural and Functional Bacterioplankton Metacommunity along a River under Anthropogenic Pressure
}

\author{
Marta Małecka-Adamowicz (D) and Łukasz Kubera *(D) \\ Department of Microbiology and Immunobiology, Faculty of Biological Sciences, Kazimierz Wielki University, \\ 85-090 Bydgoszcz, Poland; marmal@ukw.edu.pl \\ * Correspondence: kubera@ukw.edu.pl
}

Citation: Małecka-Adamowicz, M.; Kubera, Ł. Patterns of Structural and Functional Bacterioplankton

Metacommunity along a River under Anthropogenic Pressure.

Sustainability 2021, 13, 11518.

https://doi.org/10.3390/su132011518

Academic Editor: Agnieszka

Kalwasińska

Received: 20 September 2021

Accepted: 16 October 2021

Published: 18 October 2021

Publisher's Note: MDPI stays neutral with regard to jurisdictional claims in published maps and institutional affiliations.

Copyright: (c) 2021 by the authors. Licensee MDPI, Basel, Switzerland. This article is an open access article distributed under the terms and conditions of the Creative Commons Attribution (CC BY) license (https:/ / creativecommons.org/licenses/by/ $4.0 /)$.

\begin{abstract}
Bacteria, an integral part of aquatic ecosystems, are responsible for the circulation of matter and flow of energy. Since bacterioplankton rapidly responds to any natural and human-induced disturbances in the environment, it can serve as a bioindicator of these changes. Knowing factors that shape the microbial community structure may help the sustainable management of the water environment. However, the identification of environmental signals affecting the structure and function of bacterioplankton is still a challenge. The study analyses the impact of environmental variables on basic microbial parameters, which determines the effectiveness of ecological processes in rivers. Measurements of bacterioplankton abundance (BA) and extracellular enzyme activity (EEA) were based on fluorescent markers. The bacterial community structure was determined by 16S rRNA gene amplicon sequencing (Illumina). The results indicate spatial variation in bacterioplankton abundance. Temporal variation was not significant. Lipase and aminopeptidase had the highest level of activity. EEA was not correlated with bacterial abundance but was significantly correlated with temperature. Moreover, differences in lipase, $\alpha$-glucosidase and $\beta$-glucosidase activity levels between spring and summer were noted. At the same time, the location of sampling site had a significant influence on aminopeptidase activity. The taxonomic analysis of bacterioplankton communities in the Brda River indicated that, although different numbers of OTUs were recorded in the studied river sections, bacterioplankton biodiversity did not change significantly along the river with distance downstream. Anthropogenically modified river sections were characterized by the dominance of Flavobacterium (Bacterioidetes) and hgcl clade (Actinobacteria) taxa, known for their ability to produce extracellular enzymes. PCoA analysis revealed that the sites located in the lower river course (urban area) had the most similar bacterial community structure ( $\beta$-diversity). The study provides new insight into the changes in microbial communities along the river and emphasizes the potential impact of anthropogenization on these processes.
\end{abstract}

Keywords: bacterial abundance; extracellular enzyme activity; bacterial community structure; microbial diversity; metagenomic; $16 \mathrm{~S}$ rRNA; river

\section{Introduction}

Rivers are essential for humans and the environment. Not only do they provide water for domestic use, agriculture and industry, but they also offer habitats for many organisms. Due to intensive agricultural and industrial development, rivers may undergo considerable anthropogenic disturbance [1]. They change dynamically from source to mouth as a result of both natural processes and human activity [2] and are therefore exposed to physical, chemical and biological contaminants from their immediate surroundings [3]. The basic indicators of healthy rivers include the diversity and abundance of microorganisms, which play a key role in many ecological processes [4], e.g., organic matter decomposition and the circulation of its elements in biogeochemical cycles [5]. Anthropogenic factors such as agricultural and urban land use can significantly contribute to variability in the bacterioplankton communities [1]. Anthropogenic influences can include input, such as 
factors like nutrient-rich stormwater, sewage run-off and agricultural run-off, which can be rich in either inorganic nutrients from fertilizers, e.g. phosphorus, or in industrial waste enriched in heavy metals [6-8]. Since only living bacteria participate in the circulation of matter, the assessment of bacterial activity is an essential part of the investigation into the structure of bacterial populations in aquatic environments [9]. The ecological importance of these processes has encouraged research on bacterial communities and their response to changing environmental factors in various aquatic environments [10-12]. Despite continuous improvement of research tools, our understanding of bacterial communities and their response to environmental variables in freshwater ecosystems seems limited. Numerous analyses of the functional diversity of microbial communities indicate that their quantitative and metabolic potential is determined by various biotic, abiotic, and anthropogenic factors [13-15]. Knowing the factors that shape the microbial community structure may help to respond to changes in a particular environment [16] and thus, help its sustainable management. While bacterial processes in lakes are well understood $[17,18]$, they are still insufficiently investigated in rivers [19]. Therefore, it is necessary to further explore the influences that determine the functional and taxonomic structure of bacterial populations and basic ecological processes in rivers. The findings may be used to develop guidelines for the assessment of contamination dynamics, thereby serving the purpose of protecting rivers against the negative effects of increased anthropopressure and eutrophication. For this reason, forecasting changes in river ecosystem function based on microbial diversity may provide many potential benefits both for environment and humans.

The Brda, one of the main tributaries of the Vistula, the largest river in Poland, has numerous environmental and tourist values. In addition, it provides clean drinking water for a large urban population. However, despite its considerable importance to the northern regions of Poland, it has not yet been an object of a microbiological study. As a consequence, the activity and diversity of its bacterial communities are poorly understood. Due to the diversified catchment area management, the Brda River is a perfect environment for research on changes within the structure and diversity of the bacterial communities. This paper presents the results of the research on the ecology of microorganisms in the Brda River, whose particular sections are strongly affected by human activity, mainly agriculture and urbanization. The main objective was to determine to what extent environmental variables affect the structural and functional diversity of the river bacterioplankton.

\section{Materials and Methods}

Study area. The Brda, a river in northern Poland, has a total length of about $240 \mathrm{~km}$ and a catchment area of $4665.0 \mathrm{~km}^{2}$. It runs through forested, agricultural, and urban lands. The Brda River is a very popular and valuable landscape canoe trail in northern Poland. The last stretch of the river cuts through the city of Bydgoszcz (population of 350,000) and has numerous recreational and tourist functions [20]. In the northeastern part of the city, the Brda joins the Vistula, the longest river in Poland, which flows into the Baltic Sea. Moreover, the lower stretch of the Brda River is a part of international waterway E70.

Sampling strategy. Eight sampling sites were located along the Brda. Sites I (closest to the river source) and II were located in the upper river course, flowing through the forest. Sites III, IV and V were located in the middle river course, flowing through agricultural lands. Sites VI, VII and VIII were located in the lower river course, whose last section cuts through Bydgoszcz, a city with the population of 350,000. In the northeastern part of the city, the Brda joins the Vistula. The topography of the area and location of sampling sites is presented in Figure 1. Sampling was conducted in a seasonal cycle: in spring (May 2019), summer (August 2019), and autumn (October 2019). For metagenomic DNA sequencing we used water samples collected in spring, when the highest average bacterial abundance was recorded. Water samples, collected in triplicate into sterile bottles from the mid-point of the river at a depth of about $0.5 \mathrm{~m}$, were immediately transported to the laboratory and analyzed. 


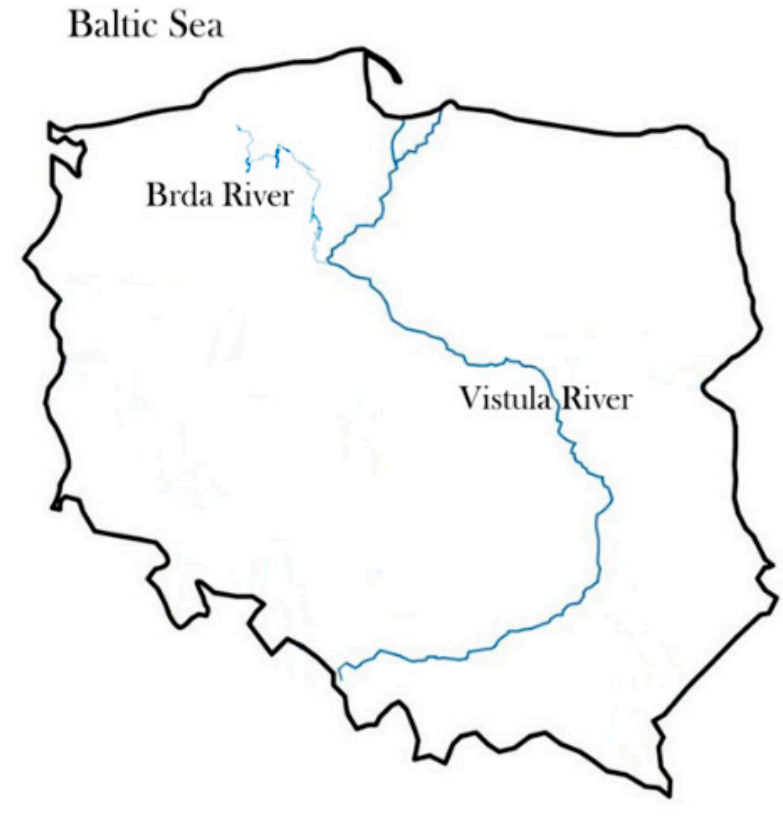

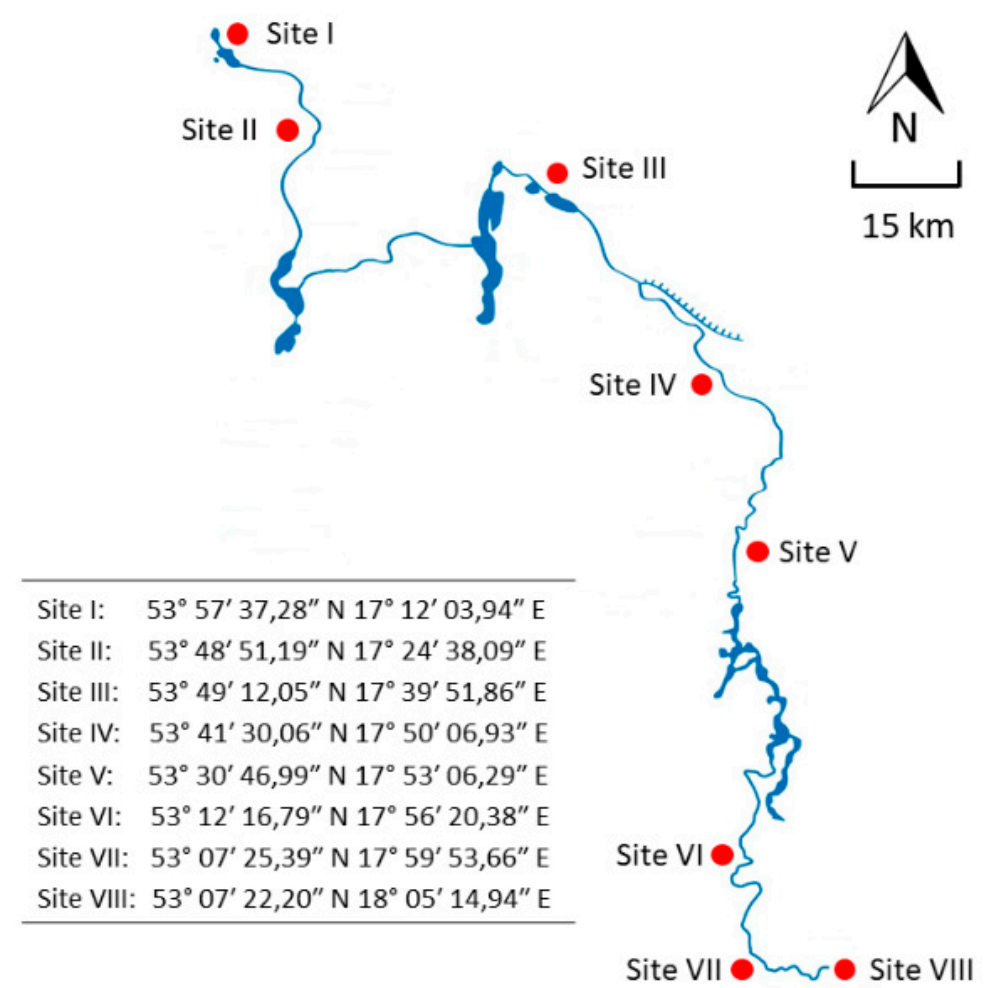

Figure 1. Arrangement of the sampling sites. The rivers are marked in blue. The sampling sites are marked in red.

Physico-chemical parameters of water. The collection of water samples was accompanied by in situ measurements of selected physico-chemical parameters of water (temperature $(\mathrm{T})$, electrolytic conductivity (EC), oxygen concentration (OC) and $\mathrm{pH}$ ), using field probes (Hanna Instruments, Deutschland). All measurements are presented in Supplementary Table S1.

Bacterial abundance. Direct counts of fluorescent-stained cells were used to determine the bacterioplankton abundance (BA). One $\mathrm{ml}$ of each water sample was transferred to sterile Eppendorf tubes and labeled with $40 \mu \mathrm{L}$ of DAPI ready-made solution $\left(4^{\prime}, 6-\right.$ diamidine- $2^{\prime}$-phenylindole dihydrochloride) at a concentration of $50 \mu \mathrm{g} \mathrm{mL}{ }^{-1}$. Samples were then incubated in the dark at room temperature and, after $15 \mathrm{~min}$, filtered through $0.2 \mu \mathrm{m}$ black membrane filters. Subsequently, the filters were rinsed with $80 \%$ ethanol and sterile water, allowed to dry, and placed on glass slides. The slides were immediately viewed using the BA410E epifluorescence microscope (Motic). The filter with an excitation wavelength of $375 \mathrm{~nm}$ and an emission wavelength of $460 \mathrm{~nm}$ was used for readings. Motic Images Advanced 3.2 software was used to count cells after their visualization.

Extracellular enzymatic activity estimation. Measurements of extracellular enzyme activity (EEA) were based on the rate of hydrolysis of fluorogenic substrate analogs [21,22]. Model organic substrates, fluorescently labeled with MUF (methyl umbeliferyl) and MCA (methyl coumarinylamide), were used to determine EEA in the Brda. Four substrates, i.e., 4-MUF-butyrate, 4-MUF- $\alpha$-D-glucoside, 4-MUF- $\beta$-D-glucoside and MCA-leucine (Lleucine-4methylocoumarinyl-7 amide), were used to measure the activity level of four enzymes, respectively: lipase, $\alpha$-glucosidase, $\beta$-glucosidase and aminopeptidase. Each substrate was dissolved in ethylene glycol monoethyl ether solution (concentration of $2 \mathrm{mM} \mathrm{L}^{-1}$ ) and stored in the dark at $25{ }^{\circ} \mathrm{C}$. Prior to the experiment, stock solutions were thawed and diluted in double-distilled ultrapure water. The portions of $3.9 \mathrm{~cm}^{3}$ of river water were poured into disposable polystyrene tubes with $0.1 \mathrm{~cm}^{3}$ of specific substrates, the final concentration of which was $60 \mu \mathrm{M} \mathrm{L}^{-1}$. Enzymatic hydrolysis was carried out in the dark at $20{ }^{\circ} \mathrm{C}$. After $60 \mathrm{~min}$, the enzymatic reaction was stopped by adding $0.1 \mathrm{~cm}^{3}$ of saturated $\mathrm{HgCl}_{2}$ solution. The increase in the fluorescence level caused by the enzymatic degradation of fluorogenic substrates was measured using the AMINCO-Bowman Series 
2 Luminescence Spectrometer (AB2 Luminescence Spectrometer version 5.5 software), calibrated with MUF and MCA solutions. The excitation/emission wavelengths were positioned at 318/445 $\mathrm{nm}$ for MUF and 345/425 nm for MCA.

Samples preparation and bacterial DNA extraction. In order to isolate bacterial DNA, $500 \mathrm{~mL}$ water samples were filtered through sterile $0.2 \mu \mathrm{m}$ black membrane filters immediately after their delivery to the laboratory. In order to avoid DNA contamination from other sources, a blank control test (filtration of water used for DNA isolation) was performed [23]. After that, the samples were stored frozen and only thawed before subsequent analyses. For the isolation of bacterial DNA deposited on the filter, DNeasy PowerWater Kit (Qiagen) was used according to protocols available in the literature [24]. The concentration of each DNA isolate was determined by fluorimetry (Qubit High Sensitivity DS. DNA Kit, Life Technologies), and its quality was checked with TapeSatation 2200 (Agilent Technologies).

Bacterial community structure. The amplification of the V3-V4 region of the bacterial 16S rRNA gene was performed according to the 16S Metagenomic Sequencing Library Preparation protocol: Preparing 16S Ribosomal RNA Gene Amplicons for the Illumina MiSeq System. For this purpose, 16S Amplicon PCR Forward Primer (5 'TCGTCGGCAGCGTCAGATGTGTATAAGAGACAGCCTACGGGNGGCWGCAG) and 16S Amplicon PCR Reverse Primer: (5' GTCTCGTGGGCTCGGAGATGTGTACHTAAGACAGGTACT) were used. The obtained libraries were subjected to paired-end sequencing using MiSeq System (Illumina). The results were analyzed using the $16 \mathrm{~S}$ Metagenomics BaseSpace app (Illumina) and the QIIME 2 bioinformatics platform, which enabled the analysis of raw DNA sequences (meta-genomic data) [25].

Bioinformatics analysis. Alpha-diversity and biodiversity indicators were calculated using the diversity plugin in the QIIME 2 (2019.7 version). The indicators were calculated based on the ASV table (amplicone sequence variant) generated by the DADA2 plugin in the same platform. In ASV, the taxonomy was classified using the classify-sklearn method based on the SILVA 132 database.

Statistical analysis. Basic statistical analyses were conducted using Statistica 13.3 software. Depending on data distribution, the analysis of intergroup differences was based on one-way ANOVA or the non-parametric Kruskal-Wallis test. Post-hoc tests were used to determine intragroup differences. Relationships between the studied groups of data were determined using the Spearman rank correlation coefficient. Rarefraction curves were constructed in phyloseq package based on calculations made in $R$ ver. 4.03. Principal component analysis (PCoA) and non-parametric multivariate analysis of variance (NPMANOVA) were performed with the same program and vegan package. Vectors of the environmental variables were fitted to the PCoA ordination using the envfit function in vegan. All statistical tests had a significance level $p \leq 0.05$.

\section{Results}

Bacterial abundance. Bacterial abundance is one of the key characteristics of bacterial populations in natural environments. As can be seen in Figure 2, the abundance of planktonic bacteria in the Brda River ranged from 10.06 cells $10^{6} \mathrm{~mL}^{-1}$ at site $\mathrm{V}$ to 23.43 cells $10^{6} \mathrm{~mL}^{-1}$ at site VII in autumn. The highest average bacterial abundance was recorded in spring ( 18.35 cells $\left.10^{6} \mathrm{~mL}^{-1}\right)$, and the lowest, in autumn $\left(15.28\right.$ cells $\left.10^{6} \mathrm{~mL}^{-1}\right)$. The highest average bacterial abundance was recorded at site VII in the city center (21.41 cells $\left.10^{6} \mathrm{~mL}^{-1}\right)$, and the lowest, at site I, at the river source $\left(13.44\right.$ cells $\left.10^{6} \mathrm{~mL}^{-1}\right)$. At sites I, II, III, IV and VI, bacterial abundance decreased seasonally, with the highest values recorded in spring, and the lowest, in autumn. However, statistical analysis did not indicate a significant correlation between bacterial abundance and season. At the same time, there were statistically significant differences in bacterial abundance $(p<0.05)$ between sites, i.e., between site I and sites VI and VII. 


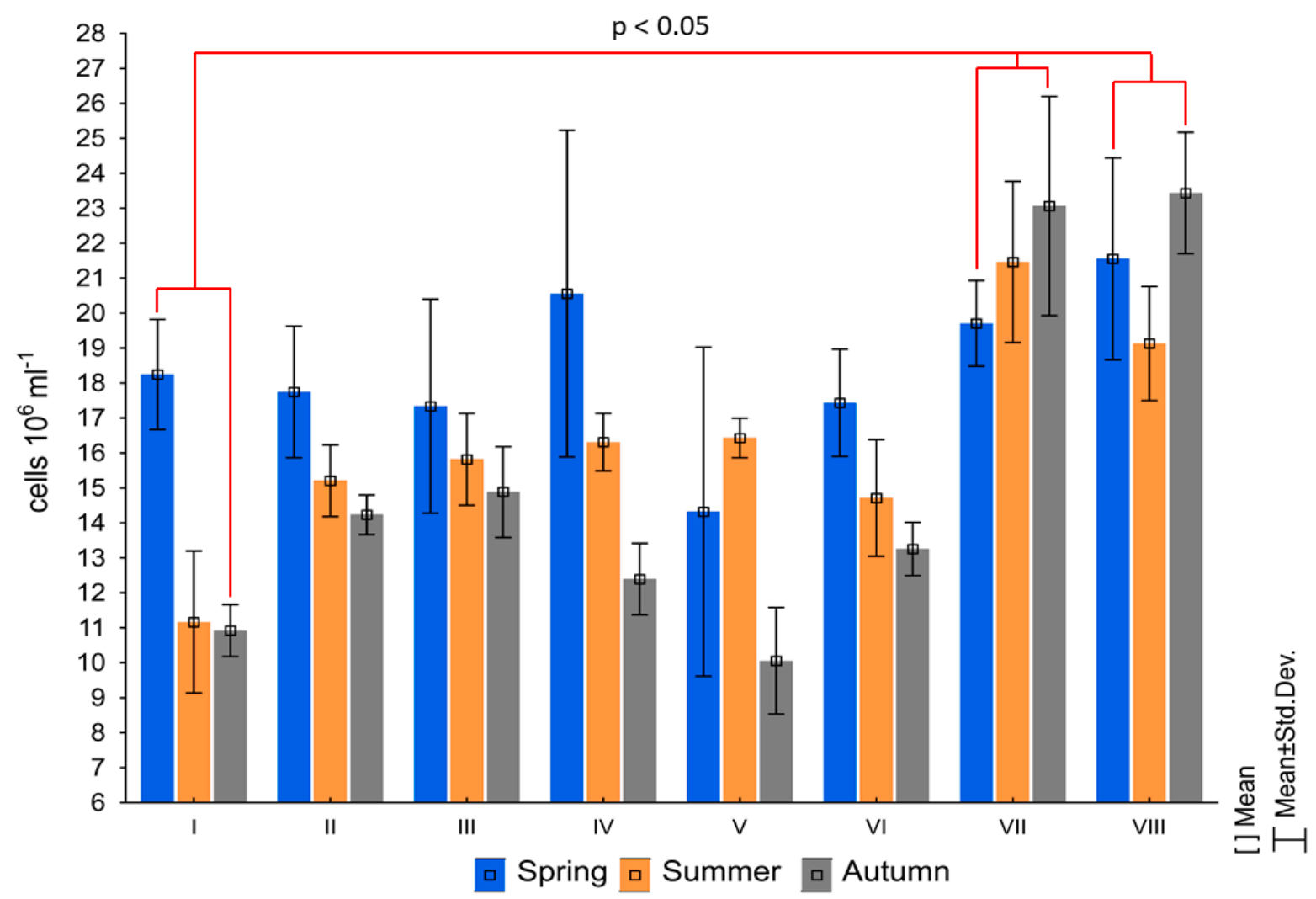

Figure 2. Bacterial abundance (BA) in Brda River marked with a DAPI fluorescent marker. Sampling sites: I-II upstream; III-V middlestream; VI-VIII downstream. Results are presented as means \pm standard deviation.

Extracellular Enzyme Activity. Figure 3 shows extracellular enzyme activity. As can be seen, lipase had the highest activity. Its fluorescence intensity, caused by the enzymatic degradation of substrates, was highest in summer in the last river section, amounting to $2561 \mathrm{nM}$ MUF $\mathrm{dm}^{-3} \cdot \mathrm{h}^{-1}$. The second-most active enzyme was aminopeptidase, with the highest activity level at site I in spring and summer, i.e., 242 and $360 \mathrm{nM} \mathrm{MCA} \mathrm{dm}{ }^{-3} \cdot \mathrm{h}^{-1}$, respectively. The $\alpha$-glucosidase and $\beta$-glucosidase had relatively low activity, with the highest values recorded at the last site in summer. In autumn, the EEA level was below the detection limit of our equipment, and this is likely related to low water temperatures in this season. EEA measurements were statistically analyzed. The analysis of variance was used to determine the probability with which environmental variables contributed to the differences between the studied groups of data (Table 1). There were significant differences in activity levels of lipase, $\alpha$-glucosidase and $\beta$-glucosidase between spring and summer. On the other hand, aminopeptidase activity was significantly correlated with the location of sampling sites. Post-hoc Tukey's test was used to explore intergroup differences; statistically significant differences $(p<0.05)$ were recorded between site I and all the remaining sites, between sites II and VI and between sites II and VIII. 
LIP
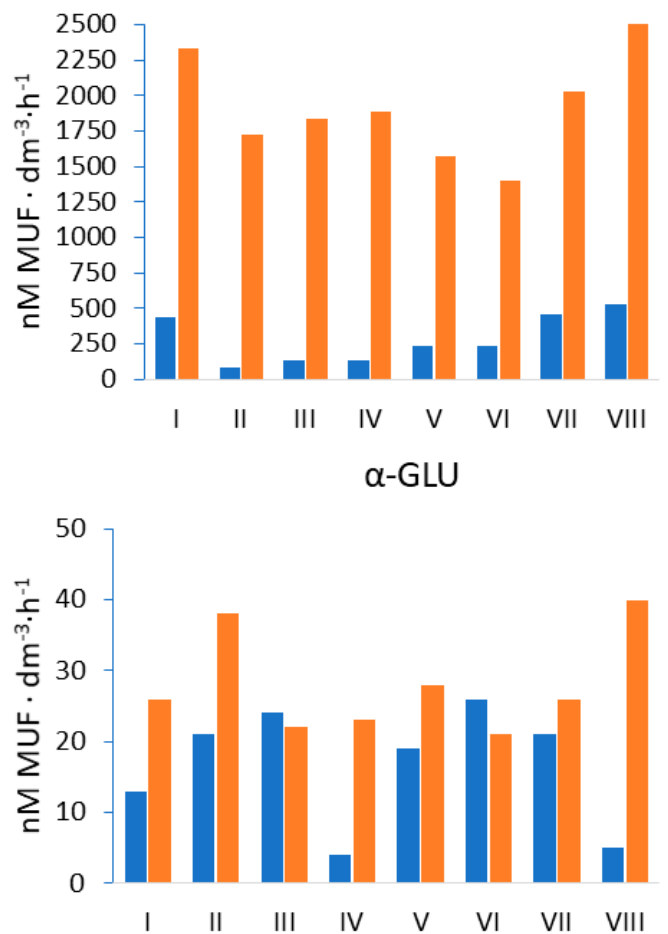
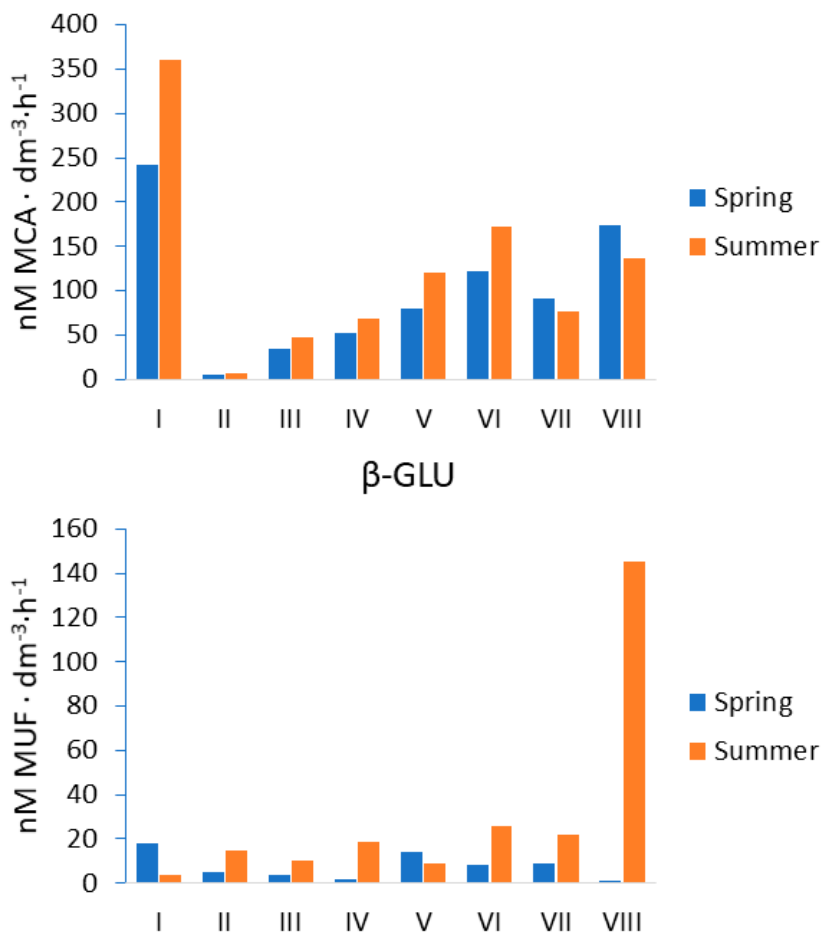

Figure 3. Extracellular enzyme activity (EEA) in the Brda River. Abbreviations: LIP-lipase, $\alpha$-GLU- $\alpha$-glucosidase, $\beta$-GLU- $\beta$-glucosidase, AMI-aminopeptidase.

Table 1. Statistical differences in the enzyme activity level between the analyzed groups of data. Statistically significant values $(p<0.05)$ are marked in red.

\begin{tabular}{cccc}
\hline Enzyme & Parameter & $p$-Value & Used Statistical Test \\
\hline Lipase & season & 0.0008 & Kruskal-Wallis \\
& sites & 0.8891 & Main Effect AVOVA \\
$\alpha$-glucosidase & season & 0.0399 & \\
& sites & 0.8112 & Kruskal-Wallis \\
$\beta$-glucosidase & season & 0.0272 & \\
& sites & 0.9851 & Main Effect ANOVA \\
Aminopeptidase & season & 0.2027 & \\
& sites & 0.0010 &
\end{tabular}

Correlations. Correlation analysis was used to evaluate the strength of a relationship between measured variables. Figure 4 shows that physico-chemical parameters of water were not correlated with the bacterioplankton abundance. As for the EEA level, statistically significant positive correlations were found only between temperature and the activity level of lipase $(r=0.84), \alpha$-glucosidase $(r=0.53)$ and $\beta$-glucosidase $(r=0.73)$. However, no statistically significant correlations were found between bacterioplankton abundance and the activity level of the measured ectoenzymes. 


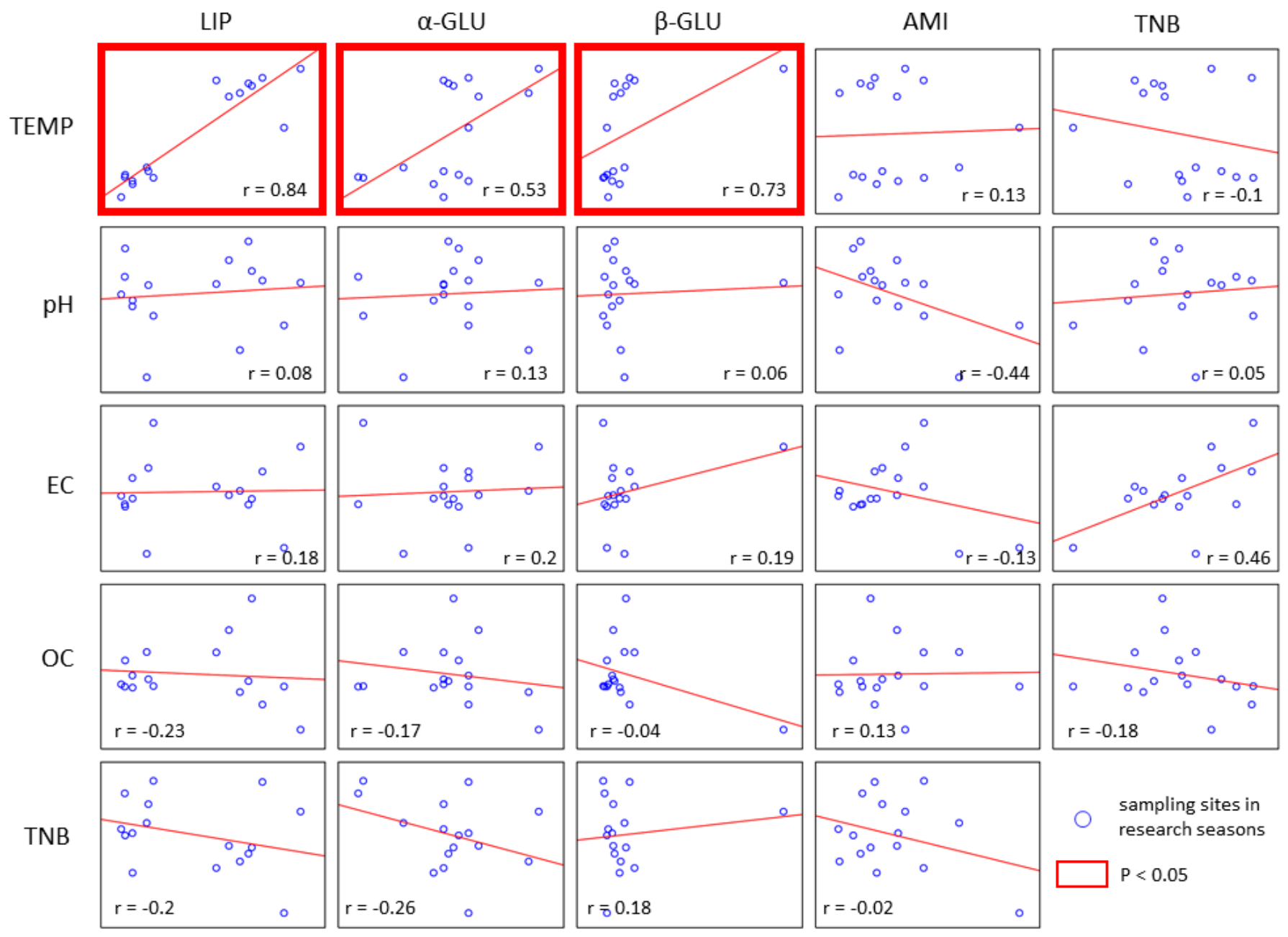

Figure 4. Influence of environmental parameters on bacterial abundance and extracellular enzyme activity. Statistically significant correlations are marked as red squares $(p<0.05)$.

Bacterial diversity and community structure. Bacterioplankton biodiversity indicators based on water metagenomic analysis are presented in Table 2 . The highest average number of OTUs was recorded in the middle river course (sites III-V). The lowest average number of OTUs was recorded in the last section of the studied river (sites VI-VIII). However, statistical analysis showed no significant differences in the number of OTUs between the upper, middle and lower river course. Moreover, the location of sampling sites did not significantly affect the biodiversity, as indicated by the Shannon-Wiener index. At the same time, small differences in species diversity were observed between sites, for which the Simpson index was 0.98. The rarefraction curves showing sampling efficiency were approaching an asymptote, which indicates that a significant part of the biodiversity was recorded (Supplementary Figure S1). At all sampling sites the proportions of five dominant bacterial phyla were similar. Taxa such as Bacterioidetes, Proteobacteria, Actinobacteria, Cyanobacteria and Verrucomicrobia prevailed (Figure 5). Bacterioidetes were the most abundant at the sites located in the middle river course, i.e., sites IV and V, accounting for $42.28 \%$ and $40.18 \%$ of the entire bacterioplankton community, respectively. An increased share of actinomycetes was recorded in the lower river course, where these microorganisms constituted about $30 \%$ of the bacterial community. Figure 6 shows the quantitative distribution of 20 most-common bacterial genera in the Brda. As can be seen, planktonic bacteria were most frequently represented by Flavobacterium species, whose share in the studied population was over $18 \%$ at sites located in the middle river course (Sites IV and V). Hgcl clade bacteria were the most abundant in the lower course, where 
at sites VI, VII and VIII they constituted about $12 \%$ of the bacterioplankton community. In the upper river course Limnohabitans $(12.02 \%)$ and Cyanobium $(11.22 \%)$ species were the most abundant, with the latter prevailing at site I (closest to the river source). PCoA analysis showed that the bacterial community structure ( $\beta$-diversity) developed along the river. In terms of taxonomy, samples from sites IV and V (midstream) and samples from sites VI-VIII (lower course) were similar (Figure 7). Furthermore, the analysis of environmental factors influencing the bacterial community structure indicated that only $\mathrm{pH}$ was influencing the microbial community at site III $(p<0.05)$. However, the NP-MANOVA analysis showed no significant differences in the microbial community structure correlated with catchment management, although the results were close to statistically significant $(p=0.057)$ (Supplementary Table S2).

Table 2. Alpha-diversity indicators of bacterioplankton in Brda River.

\begin{tabular}{cccccc}
\hline \multirow{2}{*}{ Sampling Site } & \multirow{2}{*}{ OTUs } & \multicolumn{4}{c}{ 97\% Similarity } \\
\cline { 3 - 6 } & & Shannon-Wiener & Simpson & Chao1 & ACE \\
\hline I & 728 & 7.592323 & 0.986510 & 729.885 & 731.492 \\
\hline II & 541 & 7.538064 & 0.989000 & 543.769 & 543.032 \\
\hline III & 424 & 7.233476 & 0.986403 & 424.750 & 424.860 \\
\hline IV & 719 & 7.493382 & 0.987583 & 723.550 & 722.216 \\
\hline V & 774 & 7.774601 & 0.989369 & 787.80 & 780.825 \\
\hline VI & 457 & 7.308804 & 0.987690 & 457.111 & 457.380 \\
\hline VII & 476 & 7.182502 & 0.986323 & 484.076 & 481.115 \\
\hline VIII & 518 & 7.325249 & 0.987742 & 525.50 & 522.690 \\
\hline
\end{tabular}

Note: OUT is operational taxonomic unit, Chao1 is an estimator based on abundance, ACE is abundance-based coverage estimator.

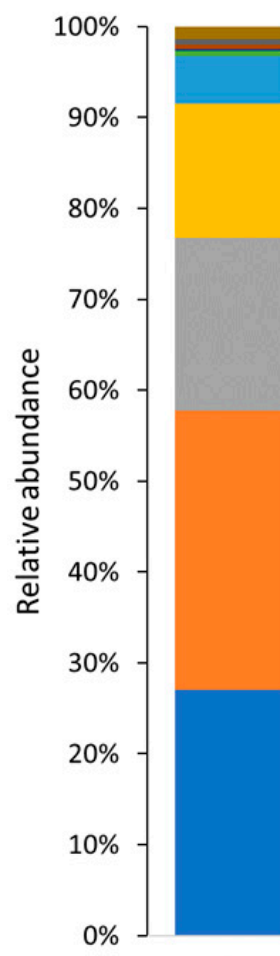

I

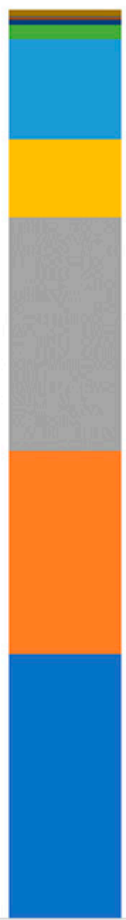

II

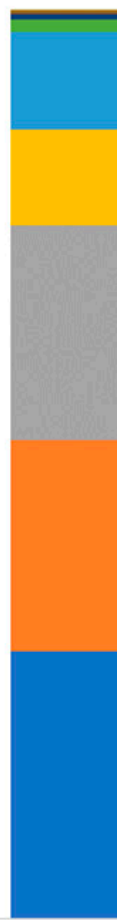

III

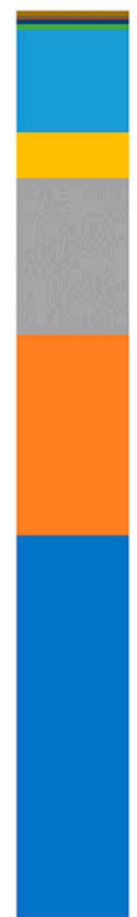

IV

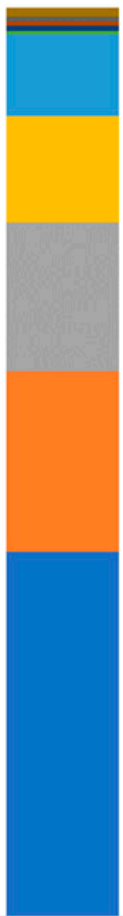

V

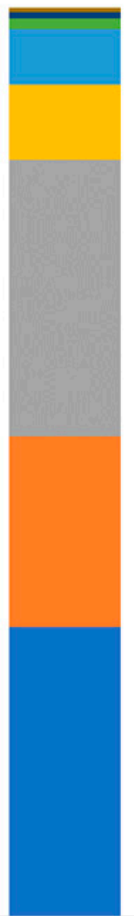

VI

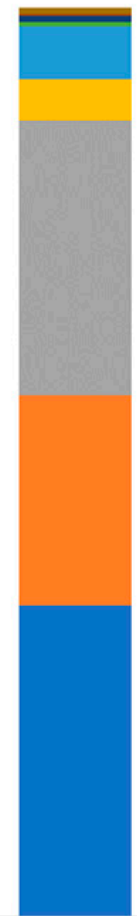

VII

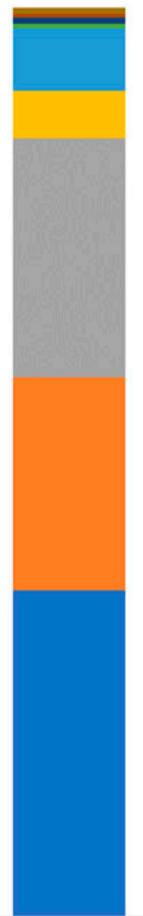

VIII

\section{Others}

- Patescibacteria

Epsilonbacteraeota

- Chloroflexi

- Planctomycetes

- Verrucomicrobia

- Cyanobacteria

- Actinobacteria

- Proteobacteria

- Bacteroidetes

Figure 5. Bacterioplankton community composition at the phylum level across all samples from the Brda River. Others-less than $1 \%$ of the total OTUs in sample. Sampling sites: I-II upstream; III-V middlestream; VI-VIII downstream. 


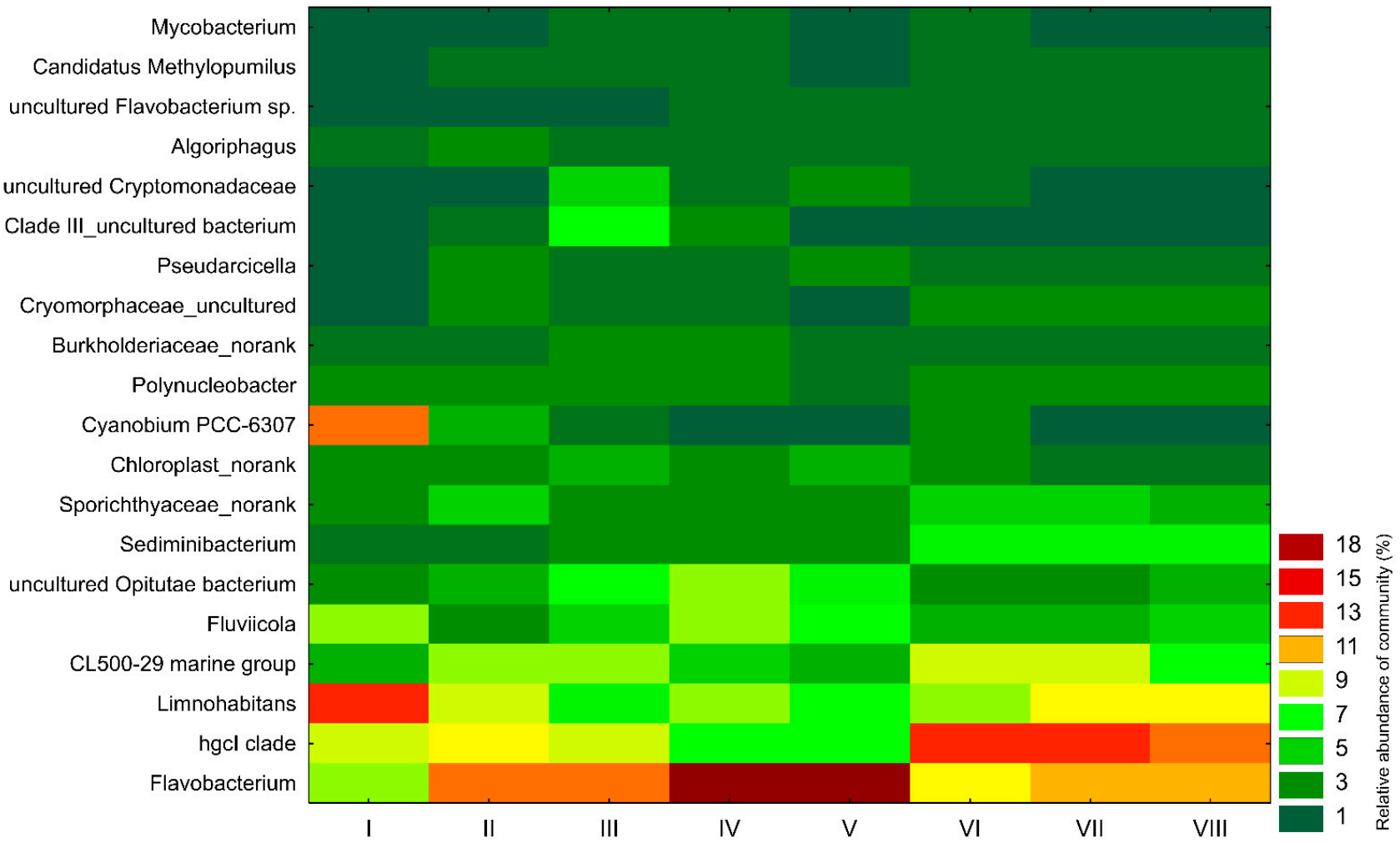

Figure 6. Heatmap of the top 20 abundant genera of bacterioplankton in each river sampling sites (I-II upstream; III-V middlestream; VI-VIII downstream).

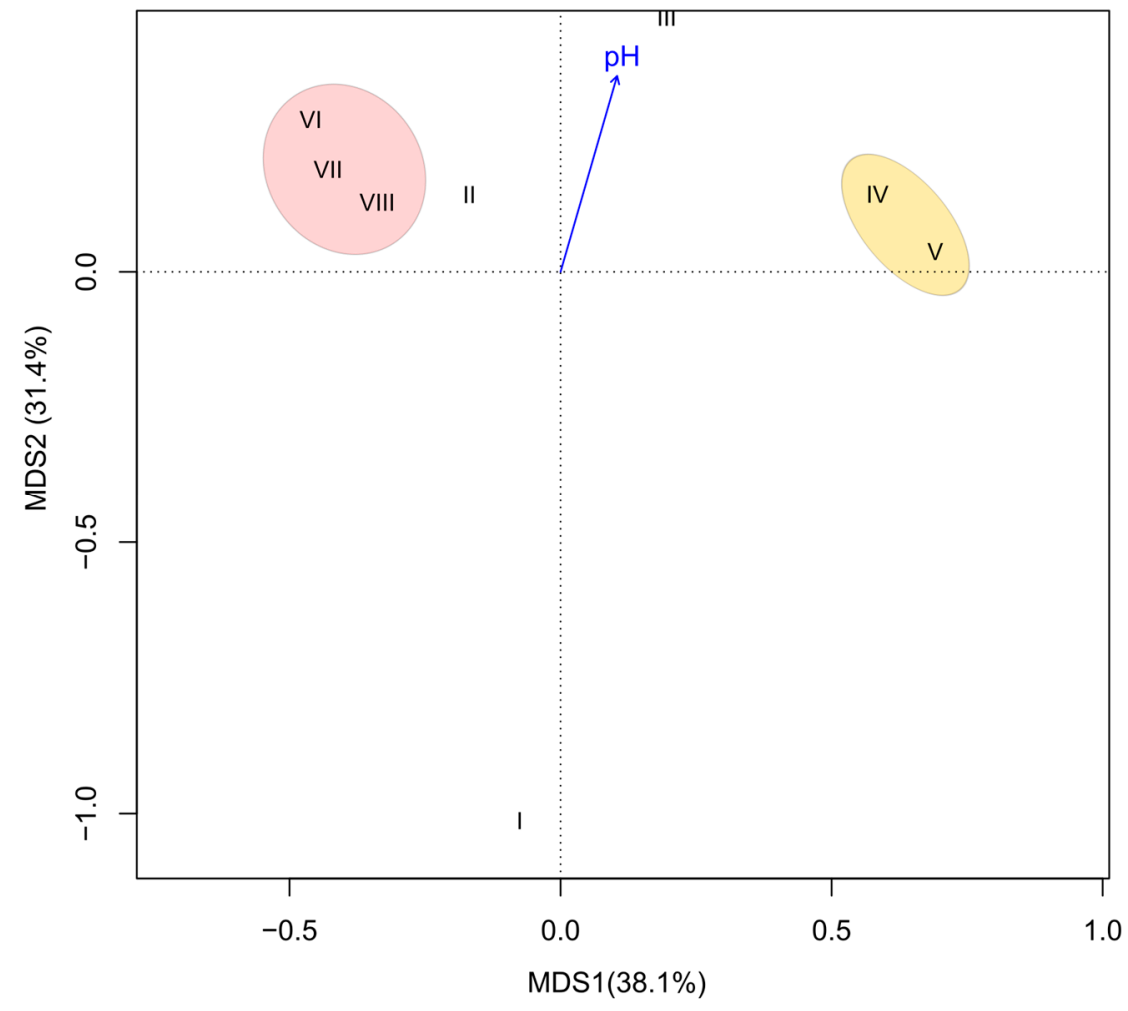

Figure 7. Principal component analysis (PCoA) of the reads obtained from the NGS sequencing of the 16SrRNA gene. 


\section{Discussion}

Determining the size and taxonomic diversity of a bacterial population, as well as type and level of cell metabolic activity, is essential for understanding the ecological functions of bacteria in aquatic environments. The assessment of bacterial abundance is among basic microbial analyses aimed at determining the role of bacteria in microbial food webs in aquatic ecosystems [26]. Recently, flow cytometry [27,28] and epifluorescence microscopy [29,30] have been widely used to count aquatic microorganisms. These techniques for the detection, identification and visualization of bacterial cells use fluorescent markers, such as DAPI, which intercalates with bacterial DNA [31]. Bacterial abundance in the Brda River, measured using the above method, is presented in Figure 2. Depending on the site and season, it ranged from 10.06 cells $10^{6} \mathrm{~mL}^{-1}$ to 23.43 cells $10^{6} \mathrm{~mL}^{-1}$. The season did not significantly affect BA, although in the upper and middle river course, it decreased in consecutive research seasons. In the lower river course in the city center (site VII), the highest value was recorded in summer, probably owing to people's increased participation in recreational activities. According to Wen et al. [32], tourism substantially contributes to the contamination of surface waters, reducing water quality. Spatial variability in the bacterioplankton abundance was observed: the highest values recorded in the lower river course at sites VII-VIII differed significantly from the values recorded in the upper river course at site I $(p<0.05)$. This might be connected with the dynamics of the river ecosystem and the accumulation of organic matter carried by the water current. In addition, in its middle course, the river flows through agricultural lands, rich in biogenic compounds from fertilizers. Similarly, Wang et al. [33] observed that the spatial distribution of bacterioplankton in the Yarlung Tsangpo River (China) was related to anthropogenic activity and increased in the upstream and midstream sites.

Due to the role that bacteria play in aquatic ecosystems and the need to understand their spatial variability, it is extremely important to analyze the impact of environmental factors on bacterioplankton communities. Our current understanding of these processes/aspects, especially with regard to the impact of physicochemical factors and anthropogenic activity (e.g., land use) on bacterioplankton in rivers, seems limited [1]. One of the most important climate factors that can regulate the activity and growth of organisms is temperature [34]. Water temperature might play crucial roles in shaping bacterioplankton community in freshwater ecosystems [14]. High temperature promotes the growth of phytoplankton, which represents a major source of organic matter for prokaryotes [35]. In the studied river, selected physico-chemical parameters (including temperature) were not significantly correlated with bacterioplankton abundance. It is likely linked to the dynamics of the river ecosystem, in which the measured parameters depended on the distance from the river source and type of catchment area management. Similar results were also obtained by other researchers studying river ecosystems, e.g., Luo et al. found a positive correlation only between BA and electrolytic conductivity in the Lancang River (China) [36]. Microbial activity is an essential parameter for the functioning of aquatic ecosystems [37]. Extracellular enzymes, functional elements of the aquatic microbial community, contribute to nutrient remineralization by accelerating organic substrate degradation [38]. Organic matter in aquatic ecosystems is a heterogeneous mixture of polymer compounds, mainly proteins, polysaccharides, chemicelluloses and lipids [39]. Since polymers are too large to be used by bacteria, extracellular enzymes hydrolyze them to monomers, which are small enough to pass through bacterial cellular membranes [40]. As is evident from Figure 3, lipase, followed by aminopeptidase, had the highest average levels of enzyme activity, while $\beta$ - and $\alpha$-glucosidase had relatively low levels. Similar results (lipase $>$ aminopeptidase $>\beta$-glucosidase $>\alpha$-glucosidase) were obtained by Perliński and Murdyk [41] in the estuary of the Słupia River. The high level of lipolytic enzyme activity has been frequently reported in various aquatic ecosystems [42-44]; in the studied section of the Brda, this was probably connected with high lipid concentration. The main sources of these compounds include, not only live and dead phytoplankton and zooplankton, but also anthropogenic pollution caused, inter alia, by tourist activity [45]. In our study, aminopeptidase also 
had a high activity level. This enzyme, widely distributed in aquatic environments, is involved in the breakdown of protein from living organisms or dead matter [46]. The statistical analysis indicated that aminopeptidase was the only enzyme whose activity was significantly correlated with the location of a sampling site. Ainsworth and Goulder [47] explained gradual differences in the activity levels of leucine aminopeptidase along the Swale River (northern England) by the presence of effluent from a nearby sewage treatment plant and the potential effect of microbiological parameters such as bacterial abundance. In this study, no correlation between BA and the activity level of any tested enzyme was observed. A-glucosidases and $\beta$-glucosidases, whose activity in aquatic environments is connected with polysaccharide degradation [48], had the lowest levels of hydrolytic activity. This may result from the fact that products of lipid and polypeptide depolymerization are better sources of carbon and energy for bacteria than products of polysaccharide hydrolysis. Zaccone and Caruso [49] also recorded a low level of $\beta$-glucosidase activity compared to other enzymes.

Extracellular enzyme activity can be regulated at the ecosystem level by various environmental factors [50]. Data presented in Table 1 show that the activity level of tested enzymes (with the exception of aminopeptidase) depended on the season and increased sharply in summer. The hypothesis about the crucial influence of temperature on enzymatic activity in the studied river section was confirmed by the analysis of a correlation between ectoenzyme activity and water parameters (Figure 4). Other authors also maintain that temperature is a key factor determining seasonal variability in extracellular enzyme activity in aquatic environments [51,52].

Bacterioplankton is an important element of aquatic ecosystems. Processes that drive microbial diversity in streams may be disturbed in response to environmental changes [53]. As a result, spatial and temporal patterns of the bacterioplankton metacommunity, as well as the impact of environmental signals, are still not fully understood. In the present study, bacterioplankton taxonomic diversity did not significantly change downstream. The highest average number of OTUs was recorded in the middle river course, which may be connected with nutrient emission from agricultural lands. Agricultural runoff may improve conditions in a range of habitats and thus increase their microbial diversity [54]. The lowest average number of OTUs was recorded in the lower, urbanized river course. Hanashiro et al. [55] suggest that urbanization does not have a direct impact on the bacterioplankton metacommunity structure and that environmental rather than spatial factors contribute to its variability. The fact that only small differences in microbial biodiversity were observed may also be connected with the biotic homogenization of the studied river, resulting from the anthropogenic modification of this ecosystem [56]. Statistical analysis did not indicate any significant impact of the location of sampling sites on bacterioplankton biodiversity in the Brda River. At all sites, similar proportions of taxa were recorded. At the phylum level they were represented by Bacterioidetes, Proteobacteria and Actinobacteria (Figure 5), which have the ability to produce a variety of extracellular enzymes and have been identified as dominant bacterial taxa in both marine [57] and riverine [30] environments. With more than $18 \%$ share in the total microbial community in the middle river course, Flavobacterium dominated at the genus level (Figure 6). These bacteria participate in nitrate reduction [58,59], which may explain their abundance at sites located in the vicinity of agricultural lands. The taxonomic profile also confirmed the presence of the hgcl-clade group (Actinobacteria), which dominated in the lower, urbanized river course, constituting about $12 \%$ of the bacterial community. Actinomycetes are among the dominant taxa in freshwater ecosystems $[60,61]$. Several genomes of these bacteria have the ability to transform organic matter that is known to be extremely resistant to degradation [62]. Karayanni et al. [63] also noted the dominance of the hgcl-clade group in ecosystems whose catchment areas were associated with urban and industrial activities. 


\section{Conclusions}

The study examines the functional and structural diversity of the Brda River bacterioplankton community. The results indicate that bacterioplankton abundance depended on the location of a sampling site but did not depend on the season of the year. Lipase and aminopeptidase had the highest activity level, which depended either on the season of the year (lipase) or the location of the sampling sites (aminopeptidase). The activity level of hydrolytic enzymes was not correlated with the bacterial abundance but was significantly correlated with temperature. The taxonomic analysis indicated that, although the individual river sections differed in the proportions of OTUs, the river flow did not significantly affect the bacterioplankton biodiversity. Anthropogenically modified river sections were characterized by the predominance of enzyme-producing taxa, such as Flavobacterium (Bacterioidetes) and hgcl clade (Actinobacteria). Obviously, certain methodological limitations, such as the number of samples or the selection of the 16S rRNA region, might have affected our results. Nevertheless, the study provides some new information about the variability of the microbial community along the river and the potential impact of anthropogenization on these processes.

Supplementary Materials: The following are available online at https://www.mdpi.com/article/ 10.3390/su132011518/s1. Table S1: Environmental parameters of water samples (mean \pm standard deviation). Table S2: NP-MANOVA results regarding groups of sampling sites subjected to different management of the catchment area. Figure S1: Rarefraction curves from NGS sequencing of the $16 \mathrm{~S}$ rRNA gene.

Author Contributions: Conceptualization, Ł.K.; Data curation, Ł.K.; Formal analysis, M.M.-A. and Ł.K.; Investigation, M.M.-A. and Ł.K.; Methodology, M.M.-A. and Ł.K.; Software, Ł.K.; Validation, Ł.K.; Visualization, Ł.K.; Writing—original draft, Ł.K.; Writing—review and editing, M.M.-A. All authors have read and agreed to the published version of the manuscript.

Funding: This study was supported by the Polish Minister of Science and Higher Education, under the program "Regional Initiative of Excellence" in 2019-2022 (Grant No. 008/RID/2018/19).

Institutional Review Board Statement: Not applicable.

Informed Consent Statement: Not applicable.

Data Availability Statement: The sequencing reads have been deposited at the NCBI Sequence Read Archive database under the BioProject accession number PRJNA713972.

Conflicts of Interest: The authors declare no conflict of interest.

\section{References}

1. Zhou, L.; Chen, W.; Sun, J.; Liu, L.; Huang, X. Spatial Variation in Bacterioplankton Communities in the Pearl River, South China: Impacts of Land Use and Physicochemical Factors. Microorganisms 2020, 8, 814. [CrossRef]

2. Gotkowska-Płachta, A.; Gołaś, I.; Korzeniewska, E.; Koc, J.; Rochwerger, A.; Solarski, K. Evaluation of the distribution of fecal indicator bacteria in a river system depending on different types of land use in the southern watershed of the Baltic Sea. Environ. Sci. Pollut. Res. 2015, 23, 4073-4085. [CrossRef]

3. Tissera, S.; Lee, S.M. Isolation of Extended Spectrum beta-lactamase (ESBL) producing bacteria from urban surface waters in Malaysia. Malays. J. Med. Sci. 2013, 20, 14-22.

4. Jeffries, T.C.; Schmitz Fontes, M.L.; Harrison, D.P.; Van-Dongen-Vogels, V.; Eyre, B.D.; Ralph, P.J.; Seymour, J.R. Bacterioplankton Dynamics within a Large Anthropogenically Impacted Urban Estuary. Front. Microbiol. 2016, 6, 1438. [CrossRef]

5. Newton, R.J.; Jones, S.E.; Eiler, A.; McMahon, K.D.; Bertilsson, S. A Guide to the Natural History of Freshwater Lake Bacteria. Microbiol. Mol. Biol. Rev. 2011, 75, 14-49. [CrossRef]

6. Beck, H.J.; Birch, G.F. Metals, nutrients and total suspended solids discharged during different flow conditions in highly urbanised catchments. Environ. Monit. Assess. 2012, 184, 637-653. [CrossRef] [PubMed]

7. Gregoracci, G.B.; Nascimento, J.R.; Cabral, A.S.; Paranhos, R.; Valentin, J.L.; Thompson, C.C.; Thompson, F.L. Structuring of bacterioplankton diversity in a large tropical bay. PLoS ONE 2012, 7, e31408. [CrossRef]

8. McCready, S.; Birch, G.F.; Long, E.R. Metallic and organic contaminants in sediments of Sydney Harbour, Australia and vicinity-A chemical dataset for evaluating sediment quality guidelines. Environ. Int. 2006, 32, 455-465. [CrossRef] [PubMed]

9. Senjarini, K.; Karsten, U.; Schumann, R. Application of Fluorescence Markers for the Diagnosis of Bacterial Abundance and Viability in Aquatic Ecosystem. J. Microbiol. Res. 2013, 3, 143-147. 
10. Cunha, M.A.; Almeida, M.A.; Alcântara, F. Short-term responses of the natural planktonic bacterial community to the changing water properties in an estuarine environment: Ectoenzymatic activity, glucose incorporation, and biomass production. Microb. Ecol. 2001, 42, 69-79. [CrossRef]

11. Wang, Y.; Liu, L.; Chen, H.; Yang, J. Spatiotemporal dynamics and determinants of planktonic bacterial and microeukaryotic communities in a Chinese subtropical river. Appl. Microbiol. Biotechnol. 2015, 99, 9255-9266. [CrossRef]

12. Du, Y.; Yang, E.; Ding, X.; Zhang, J.; Zheng, Z.; Zhu, J. High heterogeneity of bacterioplankton community shaped by spatially structured environmental factors in West Lake, a typical urban lake in eastern China. Environ. Sci. Pollut. Res. 2020, 27, 42283-42293. [CrossRef] [PubMed]

13. Meiling Zhang, M.; Yu, N.; Chen, L.; Jiang, C.; Tao, Y.; Zhang, T.; Chen, J.; Xue, D. Structure and seasonal dynamics of bacterial communities in three urban rivers in China. Aquat. Sci. 2012, 74, 113-120. [CrossRef]

14. Dai, Y.; Yang, Y.; Wu, Z.; Feng, Q.; Xie, S.; Liu, Y. Spatiotemporal variation of planktonic and sediment bacterial assemblages in two plateau freshwater lakes at different trophic status. Appl. Microbiol. Biotechnol. 2016, 100, 4161-4175. [CrossRef] [PubMed]

15. Krevš, A.; Kučinskienè, A. Microbial decomposition of sedimentary organic matter in small temperate lakes. Fundam. Appl. Limnol. 2018, 191, 239-251. [CrossRef]

16. Mansour, I.; Heppell, C.M.; Ryo, M.; Rillig, M.C. Application of the microbial community coalescence concept to riverine networks. Biol. Rev. Camb. Philos. Soc. 2018, 93, 1832-1845. [CrossRef] [PubMed]

17. Kiersztyn, B.; Chróst, R.; Kaliński, T.; Siuda, W.; Bukowska, A.; Kowalczyk, G.; Grabowska, K. Structural and functional microbial diversity along a eutrophication gradient of interconnected lakes undergoing anthropopressure. Sci. Rep. 2019, 9, 11144. [CrossRef]

18. Zhang, H.; Sekar, R.; Visser, P.M. Editorial: Microbial Ecology in Reservoirs and Lakes. Front. Microbiol. 2020, 11, 1348. [CrossRef]

19. Lu, Q.; Song, Y.; Mao, G.; Lin, B.; Wang, Y.; Gao, G. Spatial variation in bacterial biomass, community composition and driving factors across a eutrophic river. Ecotoxicol. Environ. Saf. 2020, 205, 111113. [CrossRef]

20. Kubera, Ł. Spread Patterns of Antibiotic Resistance in Faecal Indicator Bacteria Contaminating an Urbanized Section of the Brda River. Microb. Ecol. 2021, 81, 592-600. [CrossRef]

21. Hoppe, H.G. Use of fluorogenic model substrates for extracellular enzyme activity (EEA) measurement of bacteria. In Handbook of Methods in Aquatic Microbial Ecology; Kemp, P.F., Sherr, B.F., Sherr, E.B., Cole, J.J., Eds.; CRC Press: Boca Raton, FL, USA, 1993; pp. 423-432.

22. Yamada, N.; Fukuda, H.; Ogawa, H.; Saito, H.; Suzumura, M. Heterotrophic bacteria production and extracellular enzymatic activity in sinking particulate matter in the western North Pacific Ocean. Front. Microbiol. 2012, 3, 379. [CrossRef]

23. Eisenhofer, R.; Minich, J.J.; Marotz, C.; Cooper, A.; Knight, R.; Weyrich, L.S. Contamination in Low Microbial Biomass Microbiome Studies: Issues and Recommendations. Trends. Microbiol. 2019, 27, 105-117. [CrossRef]

24. Reynoso, G.; Smith, M.R.; Holmes, C.P.; Keelan, C.R.; McGrath, S.E.; Alvarez, G.H.; Coceano, M.A.; Eldridge, K.A.; Fried, H.I.; Gilbert, N.E.; et al. Bacterial community structure and response to nitrogen amendments in Lake Shenandoah (VA, USA). Water Sci. Technol. 2019, 80, 675-684. [CrossRef]

25. Bolyen, E.; Rideout, J.R.; Dillon, M.R.; Bokulich, N.A.; Abnet, C.C.; Al-Ghalith, G.A.; Alexander, H.; Alm, E.J.; Arumugam, M.; Asnicar, F.; et al. Reproducible, interactive, scalable and extensible microbiome data science using QIIME 2. Nat. Biotechnol. 2019, 37, 852-857. [CrossRef] [PubMed]

26. Gong, Y.; Tang, X.; Shao, K.; Hu, Y.; Gao, G. Dynamics of bacterial abundance and the related environmental factors in large shallow eutrophic Lake Taihu. J. Freshw. Ecol. 2017, 32, 133-145. [CrossRef]

27. Liu, J.; Tu, T.; Gao, G.; Bartlam, M.; Wang, Y. Biogeography and Diversity of Freshwater Bacteria on a River Catchment Scale. Microb. Ecol. 2019, 78, 324-335. [CrossRef]

28. Xie, G.; Tang, X.; Shao, K.; Hu, Y.; Martin, R.M.; Gao, G. Spatiotemporal patterns and environmental drivers of total and active bacterial abundances in Lake Taihu, China. Ecol. Indicat. 2020, 114, 106335. [CrossRef]

29. Kopylov, A.I.; Ievleva, T.V.; Romanenko, A.V.; Zabotkina, E.A. Structural and functional characteristics of the bacterioplankton of rivers flowing through a large city (Cherepovets, Upper Volga Region). Biol. Bull. Russ. Acad. Sci. 2016, 43, 1350-1356. [CrossRef]

30. Hu, W.; Murata, K.; Zhang, D. Applicability of LIVE/DEAD BacLight stain with glutaraldehyde fixation for the measurement of bacterial abundance and viability in rainwater. J. Environ. Sci. 2017, 51, 202-213. [CrossRef] [PubMed]

31. Muthukrishnan, T.; Govender, A.; Dobretsov, S.; Abed, R.M.M. Evaluating the Reliability of Counting Bacteria Using Epifluorescence Microscopy. J. Mar. Sci. Eng. 2017, 5, 4. [CrossRef]

32. Wen, B.; Zhang, X.; Yang, Z.; Xiong, H.; Qiu, Y. Influence of tourist disturbance on soil properties, plant communities, and surface water quality in the Tianchi scenic area of Xinjiang, China. J. Arid. Land. 2016, 8, 304-313. [CrossRef]

33. Wang, P.; Wang, X.; Wang, C.; Miao, L.; Hou, J.; Yuan, Q. Shift in bacterioplankton diversity and structure: Influence of anthropogenic disturbances along the Yarlung Tsangpo River on the Tibetan Plateau, China. Sci. Rep. 2017, 7, 12529. [CrossRef]

34. Lin, W.; Wang, Y.; Pan, Y. Short-term effects of temperature on the abundance and diversity of magnetotactic cocci. MicrobiologyOpen 2012, 1, 53-63. [CrossRef] 
35. Kubera, Ł.; Donderski, W. Distribution and activity of benthic bacteria in four lakes in the Bory Tucholskie National Park (Poland). Aquat. Microb. Ecol. 2017, 79, 127-135. [CrossRef]

36. Luo, X.; Xiang, X.; Huang, G.; Song, X.; Wang, P.; Fu, K. Bacterial Abundance and Physicochemical Characteristics of Water and Sediment Associated with Hydroelectric Dam on the Lancang River China. Int. J. Environ. Res. Public Health 2019, 16, 2031. [CrossRef] [PubMed]

37. Lew, S.; Glińska-Lewczuk, K.; Lew, M. The effects of environmental parameters on the microbial activity in peat-bog lakes. PLoS ONE 2019, 14, e0224441. [CrossRef] [PubMed]

38. Allison, S.D.; Chao, Y.; Farrara, J.D.; Hatosy, S.; Martiny, A.C. Fine-scale temporal variation in marine extracellular enzymes of coastal southern California. Front. Microbiol. 2012, 3, 301. [CrossRef] [PubMed]

39. Caruso, G. Microbial parameters as a practical tool for the functional characterization and ecological status assessment of transitional areas. J. Ecosyst. Ecograph. 2015, 5, e124. [CrossRef]

40. Arnosti, C. Speed bumps and barricades in the carbon cycle: Substrate structural effects on carbon cycling. Mar. Chem. 2004, 92, 263-273. [CrossRef]

41. Perliński, P.; Mudryk, Z.J. Enzymatic biodegradation of high molecular weight polymers in the sediment-water interface in the coastal river estuary. River Res. Applic. 2018, 34, 745-754. [CrossRef]

42. Mudryk, Z.J.; Skórczewski, P. Extracellular enzyme activity at the air-water interface of an estuarine lake. Estuar. Coast. Shelf Sci. 2004, 59, 59-67. [CrossRef]

43. Kalwasińska, A.; Swiontek Brzezinska, M. Extracellular enzymatic activities in subsurface water of eutrophic Lake Chełmżyńskie, Poland. J. Freshw. Ecol. 2013, 28, 517-527. [CrossRef]

44. Kubera, Ł.; Donderski, W. Distribution and physiological activity of heterotrophic benthic bacteria in lakes with different trophic conditions located in the Bory Tucholskie National Park (Poland). Pol. J. Natur. Sci. 2017, 32, 549-559.

45. Perliński, P.; Mudryk, Z.J.; Antonowicz, J. Enzymatic activity in the surface microlayer and subsurface water in the harbour channel. Estuar. Coast. Shelf Sci. 2017, 196, 150-158. [CrossRef]

46. Caruso, G. Leucine Aminopeptidase, beta-Glucosidase and Alkaline Phosphatase activity rates and their significance in nutrient cycles in some coastal Mediterranean sites. Mar. Drugs 2010, 8, 916-940. [CrossRef]

47. Ainsworth, A.M.; Goulder, R. Downstream change in leucine aminopeptidase activity and leucine assimilation by epilithic microbiota along the River Swale, northern England. Sci. Total. Environ. 2000, 251-252, 191-204. [CrossRef]

48. Jaramillo-Salazar, M.T.; Aguirre-Ramírez, N.J.; Galvis-García, J.H. Using extracellular enzyme activity as a pollutant indicator: A field study in Chinchiná River, Caldas-Colombia. Int. J. Environ. Prot. 2016, 6, 47-59. [CrossRef]

49. Zaccone, R.; Caruso, G. Microbial enzymes in the Mediterranean Sea: Relationship with climate changes. AIMS Microbiol. 2019, 5, 251-271. [CrossRef]

50. Cunha, A.; Almeida, A.; Coelho, F.J.R.C.; Gomes, N.C.M.; Oliveira, V.; Santos, A.L. Bacterial extracellular enzymatic activity in globally changing aquatic ecosystems. In Current Research, Technology and Education Topics in Applied Microbiology and Microbial Biotechnology; Mendez-Vilas, A., Ed.; Formatex Research Center: Badajoz, Spain, 2010; pp. 124-135.

51. Caruso, G.; Azzaro, F.; Azzaro, M.; Decembrini, F.; La Ferla, R.; Maimone, G.; De Pasquale, F.; Monticelli, L.S.; Zaccone, R.; Zappalà, G.; et al. Environmental variability in a transitional Mediterranean system (Oliveri-Tindari, Italy): Focusing on the response of microbial activities and prokaryotic abundance. Estuar. Coast. Shelf Sci. 2013, 135, 158-170. [CrossRef]

52. Zaccone, R.; Azzaro, M.; Azzaro, F.; Bergamasco, A.; Caruso, G.; Leonardi, M.; La Ferla, R.; Maimone, G.; Mancuso, M.; Monticelli, L.S.; et al. Seasonal Dynamics of Prokaryotic Abundance and Activities in Relation to Environmental Parameters in a Transitional Aquatic Ecosystem (Cape Peloro, Italy). Microb. Ecol. 2014, 67, 45-56. [CrossRef]

53. Hassell, N.; Tinker, K.A.; Moore, T.; Ottesen, E.A. Temporal and spatial dynamics in microbial community composition within a temperate stream network. Environ. Microbiol. 2018, 20, 3560-3572. [CrossRef]

54. Jordaan, K.; Bezuidenhout, C.C. Bacterial community composition of an urban river in the North West Province, South Africa, in relation to physico-chemical water quality. Environ. Sci. Pollut. Res. 2016, 23, 5868-5880. [CrossRef]

55. Hanashiro, F.T.T.; Mukherjee, S.; Souffreau, C.; Engelen, J.; Brans, K.I.; Busschaert, P.; De Meester, L. Freshwater Bacterioplankton Metacommunity Structure Along Urbanization Gradients in Belgium. Front. Microbiol. 2019, 10, 743. [CrossRef]

56. Drury, B.; Rosi-Marshall, E.; Kelly, J.J. Wastewater Treatment Effluent Reduces the Abundance and Diversity of Benthic Bacterial Communities in Urban and Suburban Rivers. Appl. Environ. Microbiol. 2013, 79, 1897-1905. [CrossRef] [PubMed]

57. Li, Y.; Sun, L.L.; Sun, Y.Y.; Cha, Q.Q.; Li, C.Y.; Zhao, D.L.; Song, X.Y.; Wang, M.; McMinn, A.; Chen, X.L.; et al. Extracellular Enzyme Activity and Its Implications for Organic Matter Cycling in Northern Chinese Marginal Seas. Front. Microbiol. 2019, 10, 2137. [CrossRef]

58. Nupur Bhumika, V.; Srinivas, T.N.R.; Kumar, P.A. Flavobacterium nitratireducens sp. nov., an amylolytic bacterium of the family Flavobacteriaceae isolated from coastal surface seawater. Int. J. Syst. Evol. Microbiol. 2013, 63, 2490-2496. [CrossRef] [PubMed]

59. Chen, W.M.; Xie, Y.R.; Kwon, S.W.; Sheu, S.Y. Flavobacterium sufflavum sp. nov., isolated from a freshwater lake. Int. J. Syst. Evol. Microbiol. 2019, 69, 1705-1713. [CrossRef] [PubMed] 
60. Li, Z.; Lu, L.; Guo, J.; Yang, J.; Zhang, J.; He, B.; Xu, L. Responses of spatial-temporal dynamics of bacterioplankton community to large-scale reservoir operation: A case study in the Three Gorges Reservoir, China. Sci. Rep. 2017, 7, 42469. [CrossRef]

61. Aguilar, P.; Dorador, C.; Vila, I.; Sommaruga, R. Bacterial Communities Associated with Spherical Nostoc Macrocolonies. Front. Microbiol. 2019, 10, 483. [CrossRef]

62. Ghai, R.; Mizuno, C.M.; Picazo, A.; Camacho, A.; Rodriguez-Valera, F. Key roles for freshwater Actinobacteria revealed by deep metagenomic sequencing. Mol. Ecol. 2014, 23, 6073-6090. [CrossRef]

63. Karayanni, H.; Macingo, S.C.; Tolis, V.; Alivertis, D. Diversity of Bacteria in Lakes with Different Chlorophyll Content and Investigation of Their Respiratory Activity through a Long-Term Microcosm Experiment. Water 2019, 11, 467. [CrossRef] 